\title{
Epidemiological status of bovine tuberculosis in the Federal District of Brazil
}

\section{Situação epidemiológica da tuberculose bovina no Distrito Federal}

\author{
Lucílio Antônio Ribeiro'; ${ }^{1}$ Vítor Salvador Picão Gonçalves ${ }^{2 *}$; \\ Priscilla Fernanda Cremer Francisco ${ }^{3}$; Ana Lourdes Arrais de Alencar Mota ${ }^{4}$; \\ Geraldo Teixeira do Nascimento ${ }^{1}$; Janaina Bitencourt Licurgo ${ }^{1}$; \\ Fernando Ferreira'; José Henrique Hildebrand Grisi-Filho; \\ José Soares Ferreira Neto5; Marcos Amaku; ; Ricardo Augusto Dias; ; Evelise \\ Oliveira Telles ${ }^{5}$; Marcos Bryan Heinemann ${ }^{5}$; José Renato Junqueira Borges ${ }^{2}$
}

\begin{abstract}
Considering the implementation of the National Program for the Control and Eradication of Animal Brucellosis and Tuberculosis (PNCEBT) in 2001, and the need to determine the epidemiological status of animal tuberculosis for future evaluation of the effectiveness of the measures laid down, the objective of this study was to estimate the prevalence and identify risk factors of bovine tuberculosis in the Federal District (DF) of Brazil, as well as to provide an input for the strategic management of PNCEBT. Field testing and data collection was carried out from February to December 2003. The DF was considered a single epidemiological region owing to the small number of existing farms, and the absence of significant differences between the region's farming enterprises, which would justify the stratification of the regional sample. A total of 278 farms were randomly sampled from the local registry database of bovine farms with reproductive activity, in which 2,019 adult cows were tuberculin tested. Only one sampled animal had a positive result, using the comparative cervical tuberculin test, resulting in a bovine tuberculosis prevalence of $0.05 \%$ [95\% CI: $0.0-0.4 \%]$. The herd-level prevalence of bovine tuberculosis in the DF was estimated as $0.36 \%$ [95\% CI: $0-2.0 \%]$. The analysis of risk factors was impaired by the results obtained, as the number of cases did not allow for this kind of analysis. Cattle farming in the DF is predominantly aimed at dairy production; however, it is characterized by the presence of small low milk yield herds, which may not favor the introduction and persistency of infection of Mycobacterium bovis. Health authorities from the DF perform surveillance for bovine tuberculosis and maintain the need for tests for the movement of bovines for breeding and those animals destined for any form of animal gathering, especially auctions. Therefore, it is likely that the DF has good conditions for successfully implementing the PNCEBT.
\end{abstract}

Key words: Bovine tuberculosis. Prevalence. Federal District. Brazil.

\footnotetext{
${ }^{1}$ Médicos Veterinários, Secretaria de Agricultura, Abastecimento e Desenvolvimento Rural do Distrito Federal, SEAGRI, Brasília, DF, Brasil. E-mail: amburana jatoba@yahoo.com.br; geraldonasc@hotmail.com; jblicurgo@yahoo.com.br

2 Profs., Faculdade de Agronomia e Medicina Veterinária, Universidade de Brasília, UnB, Brasília, Brasil. E-mail: vitorspg@unb. br; jrborges@unb.br

${ }^{3}$ Discente, Mestrado em Saúde Animal. Faculdade de Agronomia e Medicina Veterinária, UnB, Brasília, DF, Brasil. E-mail: pricremer@yahoo.com.br

${ }^{4}$ Médica Veterinária, Dr ${ }^{\mathrm{a}}$, em Saúde Animal, Faculdade de Agronomia e Medicina Veterinária, UnB, Brasília, DF, Brasil. E-mail: analourdes@unb.br

${ }^{5}$ Profs., Faculdade de Medicina Veterinária e Zootecnia, USP, São Paulo, SP, Brasil. E-mail: fernando@vps.fmvz.usp.br; grisi@ vps.fmvz.usp.br; jsoares@vps.fmvz.usp.br; amaku@vps.fmvz.usp.br; dias@vps.fmvz.usp.br, evelise@vps.fmvz.usp.br, marcosbryan@usp.br

* Author for correspondence
} 


\section{Resumo}

Considerando a implantação do Programa Nacional de Controle e Erradicação da Brucelose e Tuberculose Animal (PNCEBT) no ano de 2001 e a necessidade de se conhecer a situação epidemiológica local da tuberculose animal para uma posterior avaliação da eficácia das medidas estabelecidas, este trabalho teve como objetivo estimar a prevalência e identificar os fatores de risco para a tuberculose bovina no Distrito Federal, assim como, fornecer subsídios para a gestão estratégica do PNCETB. A colheita de dados foi realizada no período de fevereiro a dezembro de 2003. O DF foi considerado como uma única região epidemiológica devido ao número pequeno de propriedades existentes e pela ausência de diferenças importantes entre as regiões pecuárias que justificassem a estratificação regional da amostra. Foram amostradas aleatoriamente 278 propriedades do banco cadastral local de rebanhos bovinos com atividade reprodutiva, nas quais foram testadas 2019 fêmeas adultas. Somente um animal amostrado foi positivo ao Teste Cervical Comparativo, resultando numa prevalência de animais de 0,05\% [IC 95\%: 0,0-0,4\%]. A prevalência de focos de tuberculose bovina no DF foi estimada em 0,36\% [IC95\%: 0,0$2,0 \%]$. A análise de fatores de risco foi inviabilizada pelos resultados obtidos, já que o número de casos não permitiu fazer esse tipo de análise. A bovinocultura do DF é predominantemente de leite, no entanto é caracterizada pela presença de pequenos rebanhos não tecnificados, com baixa produtividade. Esta tipologia produtiva, comum na região, não deve favorecer a introdução e persistência da infecção por Mycobacterium bovis, com valores elevados de prevalência. As autoridades sanitárias do DF executam ações de vigilância para tuberculose bovina e mantêm exigência de testes para trânsito de bovinos para reprodução e com destino a aglomerações de animais, especialmente leilões, o que, certamente, contribui para que a prevalência da enfermidade seja baixa. Assim, é possível afirmar que o DF tem condições privilegiadas para implementar com sucesso o PNCEBT, devendo focar em ações de vigilância baseada em risco.

Palavras-chave: Tuberculose bovina. Prevalência. Distrito Federal. Brasil.

\section{Introduction}

The Federal District (DF) is located in the Midwest region of Brazil and has a total territorial area of 5,779,999 km² (IBGE, 2014). A large part of this area is urban, surrounded by a small rural area. Currently, the bovine and buffalo population in the DF is approximately 112,580 and 1,000 animals, respectively, based on 3,314 rural farms. These farms within the DF are typically small and are dedicated largely to dairy or mixed (beef and dairy) farming (FRANCISCO, 2008). Approximately 50\% of the farms that are dedicated to dairy production in this federation unit have up to 50 hectares of land, and only $25 \%$ of them have more than 100 hectares. The majority of herds have up to 10 adult cows, most often of cross-breeds, and produce a maximum of 15 liters of milk per day. The most frequent farming modality used in the DF is semi-confined, followed by extensive farming. Confinement is present in only $2.1 \%$ of the farms (FRANCISCO, 2008).
Considering the implementation of the National Program for the Control and Eradication of Animal Brucellosis and Tuberculosis (PNCEBT) in 2001 (BRASIL, 2001), and the need to determine the local epidemiological situation of animal tuberculosis for future evaluation of the effectiveness of the measures laid down, the objective of this work was to estimate the prevalence and identify herd-level risk factors of bovine tuberculosis in the Federal District, as well as to provide input for the strategic management of PNCEBT.

\section{Materials and Methods}

The study was designed and implemented by epidemiologists and veterinarians from the Ministry of Agriculture, Livestock and Food Supply, the University of Sao Paulo and the University of Brasília, in collaboration with the State Department of Agriculture, Supply and Rural Development (SEAGRI), DF, Brazil. Field testing and data 
collection was performed by veterinarians from the regional administrations of SEAGRI, from February to December 2003.

The DF was considered a single epidemiological region for sampling purposes, due to the small number of existing farms. Additionally, the absence of substantial differences between the farming subregions justified not regionally stratifying the sample. Sampling was carried out in two stages. Initially, 278 farms (primary sampling units) were randomly selected from the local registry database of cattle farms with reproductive activity. Within each farm, a pre-established number of cows aged greater than or equal to 24 months (secondary sampling units) were randomly selected. The sample age group is the most important subpopulation in the dynamics of bovine tuberculosis.

In cases in which the rural farms possessed more than one herd, the herd of greater economic importance (meat, milk or mixed), in which the animals were submitted to the same type of management, i.e., under the same conditions of risk, was chosen as the study target. When, for some reason, it was necessary to replace any farm initially selected, field agents were instructed to choose another farm nearby, with similar production characteristics, so as to avoid selection bias.

The equation used to estimate the sample size was proposed by Thrusfield (1995). The minimum number of primary sampling units (farms) was defined as 270 farms, considering the method of simple random sampling and the following parameters: estimated prevalence $(\mathrm{P}=5 \%)$, desired accuracy $( \pm 2.5 \%)$ and confidence level $(95 \%)$, for a target population of 3,314 rural farms.

For the calculation of secondary sampling units, an intra-herd prevalence of $20 \%$ was assumed in order to derive the number of animals that should be sampled for the detection of the disease on the farm. Simulations were performed with a herd size equal to 20 , which represented the value of the $3^{\text {rd }}$ quartile of the distribution of the number of cows above
24 months from the DF (FRANCISCO, 2008), with different cut-off points, and using Epitools ${ }^{\circledR}$ (SERGEANT, 2014). The sensitivity and specificity assumed for the comparative tuberculin test were $80 \%$ and $99.5 \%$, respectively. The criterion adopted permitted an aggregate herd-level sensitivity and specificity of approximately $90 \%$ and $99.5 \%$, respectively. In farms with up to 99 cows with ages greater than 24 months, 10 animals were sampled, while in farms with 100 or more cows aged greater than 24 months, 15 animals were sampled. The cut-off point to classify the farm as positive was the presence of at least one animal with a positive diagnostic test. Cows were chosen for testing using a random sample procedure.

The diagnostic test used was the Comparative Cervical Tuberculin Test (CCT), in accordance with the norms of PNCEBT (BRASIL, 2001). The test result was evaluated approximately 72 hours after the inoculation of bovine and avian tuberculin. A CCT reaction was considered positive when it was equal to or greater than $4 \mathrm{~mm}$ (BRASIL, 2001).

The apparent prevalence, and the respective confidence intervals, were calculated with the aid of the Epi Info 6.04d program (CDC, 2001). Considering that the sample of primary units was a simple random for the whole of the DF (COCHRAN, 1977), the apparent herd prevalence of tuberculosis was calculated by dividing the number of positive herds by the number of herds sampled. The apparent prevalence of cows older than 24 months with a positive test result was calculated considering a two-stage cluster sampling (COCHRAN, 1977) and the weight of each sampled animal, calculated using the formula below:

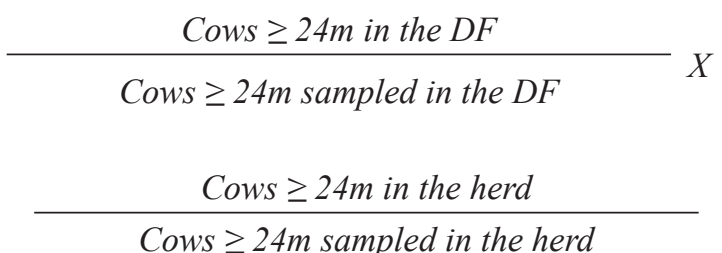

Cows $\geq 24 m$ sampled in the herd 
The first factor of this formula determines the representation of each selected animal in the DF, and the second factor determines the representation of each animal within the farm.

In each sampled farm, apart from the diagnostic test for bovine tuberculosis, an epidemiological questionnaire was also applied, in order to capture information on the productive typology and management practices for the subsequent analysis of risk factors for bovine tuberculosis in the DF. All data collected in the field were stored in a single Microsoft Access ${ }^{\circledR}$ database.

\section{Results and Discussion}

Overall, the random sample comprised 278 herds, evenly distributed throughout the rural area of the DF, out of 3,314 existing farms. The total number of adult cows sampled was 2019 from a population of 38,040 cattle of this age category. Only one animal tested positive to the CCT, resulting in a prevalence of bovine tuberculosis of $0.05 \%$ [95\% CI: 0.0 $0.4 \%$ ]. Herd prevalence in the DF was estimated as $0.36 \%$ [95\% CI: $0-2.0 \%$ ]. The analysis of risk factors was impaired by the low prevalence found, since the small number of cases did not allow us to perform this kind of analysis.

Studies based on bovine tuberculosis, conducted in 12 Federative Units, which contain $75 \%$ of the Brazilian herd, showed herd prevalence estimates between $0.5 \%$ and $9.0 \%$ in Santa Catarina and São Paulo, respectively (BAHIENSE et al., 2016; BARBIERI et al., 2016; DIAS et al., 2016; GALVIS et al., 2016; GUEDES et al., 2016; LIMA et al., 2016; NÉSPOLI et al., 2016; QUEIROZ et al., 2016; ROCHA et al., 2016; SILVA et al., 2016; VELOSO et al., 2016; VENDRAME et al., 2016). The same authors observed that the risk of bovine tuberculosis increased in larger dairy cattle herds on farms that use some degree of automation in the dairy production process. Belchior et al. (2016) described the intensification of milk production as a risk factor for bovine tuberculosis, having defined this risk factor as follows: farms that use mechanical milking, that monitor production using software, perform milk cooling, and/or have herds composed of specialized dairy breeds.

Cattle breeding in the DF predominantly consists of dairy herds, however it is characterized by the presence of small low-yield herds. The bovine population is made up of almost $78 \%$ of cross-breeds, the use of manual milking by most dairies and the low use of artificial insemination. The attention of the farmers towards genetic improvement of the herd and animal health control is still considered low (FRANCISCO, 2008). Such livestock production typology does not favor the introduction and maintenance of infection of Mycobacterium bovis in the herds.

The health authorities of the DF perform surveillance of bovine tuberculosis, and require tests for the movement of cattle for breeding or for those destined for an animal gathering, especially auctions, which may further contribute to the low disease prevalence. Therefore, it is possible that the DF has optimal conditions for successfully implementing the PNCEBT and should focus on risk-based surveillance actions. The involvement of the industry, both in financing and in the development of PNCETB policies in the DF, should be encouraged as the sharing of costs and responsibilities between the government and private initiatives increases the likelihood of success of health programs (FERREIRA NETO; BERNADI, 1997). The creation of compensation funds for farmers would also encourage the removal of an animal with a positive test result from a farm and ensure the achievement of free-herd accreditation (RADUNZ, 2006).

\section{Conclusion}

The prevalence of bovine tuberculosis is low in the DF. This might be explained by the characteristics of the cattle production systems in the region, where small low-yield diary or mixed 
herds with cross-breeds predominate, as well as by the efforts to control animal movements and cattle gatherings implemented by the animal health authorities.

\section{Acknowledgements}

The authors acknowledge the logistical and financial support from MAPA, SEAGRI-DF, CNPq and FAPESP.

\section{References}

BAHIENSE, L.; ÁVILA, L. N. de; BAVIA, M. E.; AMAKU, M.; DIAS, R. A.; GRISI-FILHO, J. H. H.; FERREIRA, F.; TELLES, E. O.; GONÇALVES, V. S. P.; HEINEMANN, M. B.; FERREIRA NETO, J. S. Prevalence and risk factors for bovine tuberculosis in the State of Bahia, Brazil. Semina: Ciências Agrárias, Londrina, v. 37, n. 5, p. 3549-3560, 2016. Suplemento 2.

BARBIERI, J. M.; OLIVEIRA, L. F.; DORNELES, E. M. S.; MOTA, A. L. A. A.; GONÇALVES, V. S. P.; MALUF, P. P.; FERREIRA NETO, J. S.; FERREIRA, F.; DIAS, R. A.; TELLES, E. O.; GRISI-FILHO, J. H. H.; HEINEMANN, M. B.; AMAKU, M.; LAGE, A. P. Epidemiological status of bovine tuberculosis in the state of Minas Gerais, Brazil. Semina: Ciências Agrárias, Londrina, v. 37, n. 5, p. 3531-3548, 2016. Suplemento 2.

BELCHIOR, A. P. C.; LOPES, L. B.; GONÇALVES, V. S. P.; LEITE, R. C. Prevalence and risk factors for bovine tuberculosis in Minas Gerais State, Brazil. Tropical Animal Health and Production, Edinburg, v. 48, n. 2, p. 373-378, 2016.

BRASIL. Instrução Normativa $n^{\circ} 2$, de 10 de janeiro de 2001. Aprova o Regulamento Técnico do Programa Nacional de Controle e Erradicação da Brucelose e Tuberculose Animal. Diário Oficial [da] União, Brasília, 16 jan. 2001. Disponível em: <http://sistemasweb. agricultura.gov.br/sislegis/action/detalhaAto. do? method $=$ detalharAtosArvore\&tipo $=I N M \&$ numero A to $=00000002 \&$ seqA to $=000 \&$ valorAno $=2001 \&$ orgao $=$ SDA $/$ MAA\& $\operatorname{codTipo}=\&$ desItem $=\&$ desItemFim $=\#>$. Accessed at: 31 oct 2014.

CENTER FOR DISEASES CONTROL AND PREVENTION - CDC. EPIINFO 6.04d. Atlanta: 2001. Available at: $<$ http://www.cdc.gov $>$. Accessed at: 09 abr. 2008.
COCHRAN, W. G. Sampling techniques. $3^{\text {th }}$ ed. New York: John Wiley \& Sons, 1977. 428 p.

DIAS, R. A.; STANOJLOVIC, F. M. U.; BELCHIOR, A. P. C.; FERREIRA, R. S.; GONÇALVES, R. C.; AGUIAR, R. S. C. B.; SOUSA, P. R.; SANTOS, A. M. A.; AMAKU, M.; FERREIRA, F.; TELLES, E. O.; GRISI-FILHO, J. H. H.; GONÇALVES, V. S. P.; HEINEMANN, M. B.; FERREIRA NETO, J. S. Prevalence and risk factors for bovine tuberculosis in the state of São Paulo, Brazil. Semina: Ciências Agrárias, Londrina, v. 37, n. 5, p.36733684, 2016. Suplemento 2.

FERREIRA NETO, J. S.; BERNADI, F. O. O controle da tuberculose bovina. Higiene Alimentar, v. 11, n. 47, p. 9-13, 1997.

FRANCISCO, P. F. C. Caracterização do ambiente pecuário e análise de prevalência de brucelose e tuberculose bovinas no Distrito Federal. 2008. Monografia (Trabalho de Conclusão de Graduação em Medicina Veterinária) - Universidade de Brasília, Brasília.

GALVIS, J. O. A.; GRISI-FILHO, J. H. H.; COSTA, D.; SAID, A. L. P. R.; AMAKU, M.; DIAS, R. A.; FERREIRA, F.; GONÇALVES, V. S. P.; HEINEMANN, M. B.; TELLES, E. O.; FERREIRA NETO, J. S. Epidemiologic characterization of bovine tuberculosis in the state of Espírito Santo, Brazil. Semina: Ciências Agrárias, Londrina, v. 37, n. 5, p. 3567-3578, 2016. Suplemento 2 .

GUEDES, I. B.; BOTTENE, I. F. N.; MONTEIRO, L. A. R. C.; LEAL FILHO, J. M.; HEINEMANN, M. B.; AMAKU, M.; GRISI-FILHO, J. H. H.; DIAS, R. A.; FERREIRA, F.; TELLES, E. O.; GONÇALVES, V. S. P.; FERREIRA NETO, J. S. Prevalence and risk factors for bovine tuberculosis in the state of Mato Grosso do Sul, Brazil. Semina: Ciências Agrárias, Londrina, v. 37, n. 5, p. 3579-3588, 2016. Suplemento 2.

INSTITUTO BRASILEIRO DE GEOGRAFIA E ESTATÍSTICA - IBGE. Estados@ - Santa Catarina: Síntese. 2014. Disponível em: <http://www.ibge.gov.br/ estadosat/perfil.php?sigla=df\#>. Acesso em 15 jun. 2015.

LIMA, P. B.; NASCIMENTO, D. L.; ALMEIDA, E. C.; PONTUAL, K. A. Q.; AMAKU, M.; DIAS, R. A.; FERREIRA, F.; GONÇALVES, V. S. P.; TELLES, E. O.; GRISI-FILHO, J. H. H.; HEINEMANN, M. B.; SILVA, J. C. R.; FERREIRA NETO, J. S. Epidemiological situation of bovine tuberculosis in the state of Pernambuco, Brazil. Semina: Ciências Agrárias, Londrina, v. 37, n. 5, p. 3601-3610, 2016. Suplemento 2. 
NÉSPOLI, J. M. B.; NEGREIROS, R. L.; AMAKU, M.; DIAS, R. A.; FERREIRA, F.; TELLES, E. O.; HEINEMANN, M. B.; GRISI-FILHO, J. H. H.; GONÇALVES, V. S. P.; FERREIRA NETO, J. S. Epidemiological situation of bovine tuberculosis in the state of Mato Grosso, Brazil. Semina: Ciências Agrárias, Londrina, v. 37, n. 5, p. 3589-3600, 2016. Suplemento 2.

QUEIROZ, M. R.; GROFF, A. C. M.; SILVA, N. S.; GRISI-FILHO, J. H. H.; AMAKU, M.; DIAS, R. A.; TELLES, E. O.; HEINEMANN, M. B.; FERREIRA NETO, J. S.; GONÇALVES, V. S. P.; FERREIRA, F. Epidemiological status of bovine tuberculosis in the state of Rio Grande do Sul, Brazil. Semina: Ciências Agrárias, Londrina, v. 37, n. 5, p. 3647-3658, 2016. Suplemento 2.

RADUNZ, B. Surveillance and risk management during the latter stages of eradication: experiences from Australia. Veterinary Microbiology, Barcelona, v. 112, n. 2-4, p. 283-290, 2006.

ROCHA, W. V.; JAYME, V. S.; MOTA, A. L. A. A.; BRITO, W. M. E. D.; PIRES, G. R. C.; GRISI-FILHO, J. H. H.; DIAS, R. A.; AMAKU, M.; TELLES, E. O.; HEINEMANN, M. B.; FERREIRA, F.; FERREIRA NETO, J. S.; GONÇALVES, V. S. P. Prevalence and herd-level risk factors of bovine tuberculosis in the State of Goiás, Brazil. Semina: Ciências Agrárias, Londrina, v. 37, n. 5, p. 3625-3628,, 2016. Suplemento 2.

SERGEANT, E. S. G. Epitools epidemiological calculators. AusVet Animal Health Services and Australian Biosecurity Cooperative Research Centre for
Emerging Infectious Disease. [S.1.: s.n.], 2014. Available at: <http://epitools.ausvet.com.au>. Access at: 22 May 2014.

SILVA, M. C. P.; GONÇALVES, V. S. P.; MOTA, A. L. A. A.; KOLODA, M.; FERREIRA NETO, J. S.; GRISIFILHO, J. H. H.; DIAS, R. A.; AMAKU, M.; TELLES, E. O.; FERREIRA, F.; HEINEMANN, M. B.; ALFIERI, A. A.; MULLER, E. E. Prevalence and herd-level risk factors for bovine tuberculosis in the state of Paraná, Brazil. Semina: Ciências Agrárias, Londrina, v. 37, n. 5, p. 3611-3624, 2016. Suplemento 2.

THRUSFIELD, M. Veterinary epidemiology. $2^{\text {th }}$ ed. Cambridge: Blackwell Science, 1995. 479 p.

VELOSO, F. P.; BAUMGARTEN, K. D.; MOTA, A. L. A. A.; FERREIRA, F.; FERREIRA NETO, J. S.; GRISI-FILHO, J. H. H.; DIAS, R. A.; AMAKU, M.; TELLES, E. O.; HEINEMANN, M. B.; GONÇALVES, V. S. P. Prevalence and herd-level risk factors of bovine tuberculosis in the State of Santa Catarina, Brazil. Semina: Ciências Agrárias, Londrina, v. 37, n. 5, p. 3659-3672, 2016. Suplemento 2.

VENDRAME, F. B.; AMAKU, M.; FERREIRA, F.; TELLES, E. O.; GRISI-FILHO, J. H. H.; GONÇALVES, V. S. P.; HEINEMANN, M. B.; FERREIRA NETO, J. S.; DIAS, R. A. Epidemiologic characterization of bovine tuberculosis in the State of Rondônia, Brazil. Semina: Ciências Agrárias, Londrina, v. 37, n. 5, p. 3639-3646, 2016. Suplemento 2. 